\title{
What is the Main Cause of Cancer?
}

\author{
Miguel López-Lázaro* \\ Department of Pharmacology, Faculty of Pharmacy, University of Seville, Spain
}

${ }^{*}$ Correspondence to: Miguel López-Lázaro, Department of Pharmacology, Faculty of Pharmacy, University of Seville, c/o Professor Garcia Gonzalez 2, 41012, Seville, Spain, Tel: +34 9545563 48, Fax: + 349545560 74; E-mail: mlopezlazaro@us.es

Received: August 10,2016; Accepted: September 10, 2016; Published: October 01, 2016

\section{Editorial}

Tobacco use, most people would say. Smoking tobacco increases the risk of developing many types of cancer and is responsible for approximately one-third of all cancer deaths. The association between tobacco use and lung cancer is well known; lung cancer occurs about 20 times more often in heavy smokers than in nonsmokers [1]. However, many lung cancers are diagnosed in never smokers [2], and most smokers do not develop lung cancer $[3,4]$.

Aging, many epidemiologists would probably say. According to SEER cancer statistics review, 1975-2012, cancer incidence increases dramatically with age [5]. The risk of being diagnosed with cancer is 1 in 128 in people under 30 years old, 1 in 10 in people between 30 and 60 , and 1 in 3 in people over 60 . The rise is more pronounced for the most common cancers. Breast, colon, lung and prostate cancers are over 150 times, 180 times, 600 times and 2,800 times more frequently diagnosed in people over 60 years old than in people under 30 . However, cancer incidence decreases late in life for most cancers; men in their 80s have approximately half the risk of developing prostate cancer than men in their 70s. In addition, the risk of some cancers does not correlate well with age; brain cancer and leukemia are more frequently diagnosed in the first decade of life than in one of the following three decades [5].

The self-renewal capacity of the body tissues, some researchers might say. Tissues with a high self-renewal capacity give rise to cancer almost a million times more often than tissues without this capacity. The incidence of breast, prostate or lung cancer is approximately seven cases per 100 people [5], whereas the incidence of heart cancer is 34 cases per 100 million people [6]. Lung cancer in nonsmokers is about 10,000 times more common than heart cancer in smokers $[5,6]$. However, some tissues with similar self-renewal capacities have different cancer risks [7].

The accumulation of mutations in oncogenes and tumor suppressor genes, many cancer researchers would conclude [8-10]. However, other cancer researchers would present evidence challenging this theory, e.g., sequencing studies showing zero genetic mutations in human tumor samples, and human studies linking non-mutagenic agents with increased cancer risks [11-16]. It has repeatedly been shown that the risk of developing cancer is increased by a variety of nonmutagenic factors, including hormone therapy (several cancer types) [17-19], drinking very hot beverages (esophageal cancer) [20-22], shift work that involves circadian disruption (breast cancer) [23-25], and exposure to non-ionizing electromagnetic fields (childhood leukemia) [26-31]. Carcinogenesis experiments in laboratory rodents have also shown that non-mutagenic factors can have a major impact on cancer incidence. Implanting foreign bodies of different materials under the skin of rodents leads to the formation of tumors; the shape of the implanted material, but not the composition, determines tumorigenesis [11,32-34]. For example, all mice implanted with Millipore filters with a pore size of 0.025 micrometers developed tumors, whereas none of the animals implanted with filters with pore sizes equal or higher than 0.22 micrometers developed any malignancy [32]. There is also consistent evidence that interruption of nerve connections alters cancer incidence and tumor growth. For example, the early phases of prostate tumor development are prevented by surgical interruption of the sympathetic nervous system [35]. Denervation of the stomach also suppresses gastric tumorigenesis [36].

It is known that cancer is ultimately caused by an uncontrolled cell proliferation that threatens life. The uncontrolled cell division of some cells leads to the accumulation of abnormal cell populations that threaten life by interfering with vital body functions [16]. However, despite decades of research, the main biological cause of such an uncontrolled proliferation remains to be elucidated. Not having the answer to the question raised in this Editorial is a major barrier to reducing the burden of the disease [37]. To be widely accepted, the answer should explain the striking differences in cancer risk by age and among tissues. It should also explain why non-mutagenic agents increase the risk of developing the disease. Cancer Studies and Therapeutics welcomes submissions addressing this key question.

\section{References}

1. Doll R, Peto R, Wheatley K, Gray R, Sutherland I. Mortality in relation to smoking: 40 years' observations on male British doctors. BMJ. 1994; 309(6959): 901-911.

2. Sun S, Schiller JH, Gazdar AF (2007) Lung cancer in never smokers--a different disease. Nat Rev Cancer 7: 778-790. [crossref]

3. Villeneuve PJ, Mao Y (1994) Lifetime probability of developing lung cancer, by smoking status, Canada. Can J Public Health 85: 385-388. [crossref]

4. Bach PB, Kattan MW, Thornquist MD, Kris MG, Tate RC, et al. (2003) Variations in lung cancer risk among smokers. J Natl Cancer Inst 95: 470-478. [crossref]

5. SEER Cancer Statistis Review, 975-2012. http://seer.cancer.gov/archive/ csr/1975_2012/results_merged/topic_lifetime_risk.pdf

6. Oliveira GH, Al-Kindi SG, Hoimes C, Park SJ2 (2015) Characteristics and Survival of Malignant Cardiac Tumors: A 40-Year Analysis of $>500$ Patients. Circulation 132: 2395-2402. [crossref]

7. Tomasetti C, Vogelstein B (2015) Cancer etiology. Variation in cancer risk among tissues can be explained by the number of stem cell divisions. Science 347: 78-81. [crossref]

8. Vogelstein B, Kinzler KW (2004) Cancer genes and the pathways they control. Nat Med 10: 789-799. [crossref] 
9. Vaux DL (2011) In defense of the somatic mutation theory of cancer. Bioessays 33: 341-343. [crossref]

10. Vogelstein B, Kinzler KW (2015) The Path to Cancer --Three Strikes and You're Out. N Engl J Med 373: 1895-1898. [crossref]

11. Baker SG (2014) A cancer theory kerfuffle can lead to new lines of research. J Natl Cancer Inst 107. [crossref]

12. Mack SC, Witt H, Piro RM, Gu L, Zuyderduyn S, et al. (2014) Epigenomic alterations define lethal CIMP-positive ependymomas of infancy. Nature 506: 445-450. [crossref]

13. Versteeg R1 (2014) Cancer: Tumours outside the mutation box. Nature 506: 438439. [crossref]

14. Soto AM, Sonnenschein C. The somatic mutation theory of cancer: growing problems with the paradigm? Bioessays. 2004; 26(10): 1097-1107.

15. López-Lázaro M (2015) Stem cell division theory of cancer. Cell Cycle 14: 25472548. [crossref]

16. Lopez-Lazaro M. Understanding cancer: 15 questions and answers. ResearchGate, 2016; DOI: 10.13140/RG.2.1.4180.6323: http://dx.doi.org/10.13140/RG.2.1.4180.6323.

17. Beral V; Million Women Study Collaborators (2003) Breast cancer and hormonereplacement therapy in the Million Women Study. Lancet 362: 419-427. [crossref]

18. Grady D, Gebretsadik T, Kerlikowske K, Ernster V, Petitti D (1995) Hormone replacement therapy and endometrial cancer risk: a meta-analysis. Obstet Gynecol 85: 304-313. [crossref]

19. Mørch LS, Løkkegaard E, Andreasen AH, Krüger-Kjaer S, Lidegaard O (2009) Hormone therapy and ovarian cancer. JAMA 302: 298-305. [crossref]

20. Islami F, Pourshams A, Nasrollahzadeh D, Kamangar F, Fahimi S, et al. (2009) Tea drinking habits and oesophageal cancer in a high risk area in northern Iran: population based case-control study. BMJ 338: b929. [crossref]

21. Islami F, Boffetta P, Ren JS, Pedoeim L, Khatib D, et al. (2009) High-temperature beverages and foods and esophageal cancer risk--a systematic review. Int $J$ Cancer 125: 491-524. [crossref]

22. Loomis D, Guyton KZ, Grosse Y, Lauby-Secretan B, El Ghissassi F, et al. (2016) Carcinogenicity of drinking coffee, mate, and very hot beverages. Lancet Oncol 17: 877-878. [crossref]

23. Schernhammer ES, Laden F, Speizer FE, Willett WC, Hunter DJ, et al. (2001) Rotating night shifts and risk of breast cancer in women participating in the nurses' health study. J Natl Cancer Inst 93: 1563-1568. [crossref]

24. Hansen J (2001) Increased breast cancer risk among women who work predominantly at night. Epidemiology 12: 74-77. [crossref]
25. Stevens RG, Brainard GC, Blask DE, Lockley SW, Motta ME (2014) Breast cancer and circadian disruption from electric lighting in the modern world. CA Cancer $J$ Clin 64: 207-218. [crossref]

26. 26. Ahlbom A, Day N, Feychting M, Roman E, Skinner J, Dockerty J, Linet M, McBride M, Michaelis J, Olsen JH, Tynes T, Verkasalo PK. A pooled analysis of magnetic fields and childhood leukaemia. Br. J. Cancer. 2000; 83(5): 692-698.

27. Greenland S, Sheppard AR, Kaune WT, Poole C, Kelsh MA (2000) A pooled analysis of magnetic fields, wire codes, and childhood leukemia. Childhood Leukemia-EMF Study Group. Epidemiology 11: 624-634. [crossref]

28. Kheifets L, Ahlbom A, Crespi CM, Draper G, Hagihara J, et al. (2010) Pooled analysis of recent studies on magnetic fields and childhood leukaemia. $\mathrm{Br} J$ Cancer 103: 1128-1135. [crossref]

29. Zhao L, Liu X, Wang C, Yan K, Lin X, et al. (2014) Magnetic fields exposure and childhood leukemia risk: a meta-analysis based on 11,699 cases and 13,194 controls. Leuk Res 38: 269-274. [crossref]

30. Grellier J, Ravazzani P, Cardis E (2014) Potential health impacts of residential exposures to extremely low frequency magnetic fields in Europe. Environ Int 62: 55-63. [crossref]

31. Schuz J, Dasenbrock C, Ravazzani P, Roosli M, Schar P, Bounds PL, Erdmann F, Borkhardt A, Cobaleda C, Fedrowitz M, Hamnerius Y, Sanchez-Garcia I, Seger R et al. Extremely low-frequency magnetic fields and risk of childhood leukemia: A risk assessment by the ARIMMORA consortium. Bioelectromagnetics. 2016; 10.

32. Karp RD, Johnson KH, Buoen LC, Ghobrial HK, Brand I, et al. (1973) Tumorigenesis by Millipore filters in mice: histology and ultrastructure of tissue reactions as related to pore size. J Natl Cancer Inst 51: 1275-1285. [crossref]

33. Ferguson DJ (1977) Cellular attachment to implanted foreign bodies in relation to tumorigenesis. Cancer Res 37: 4367-4371. [crossref]

34. Moizhess TG (2008) Carcinogenesis induced by foreign bodies. Biochemistry (Mosc) 73: 763-775. [crossref]

35. Magnon C, Hall SJ, Lin J, Xue X, Gerber L, et al. (2013) Autonomic nerve development contributes to prostate cancer progression. Science 341: 1236361. [crossref]

36. Zhao CM, Hayakawa Y, Kodama Y, Muthupalani S, Westphalen CB, et al. (2014) Denervation suppresses gastric tumorigenesis. Sci Transl Med 6: 250 ra115. [crossref]

37. Fitzmaurice C, Dicker D, Pain A, Hamavid H, Moradi-Lakeh M, MacIntyre MF, Allen C, Hansen G, Woodbrook R, Wolfe C, Hamadeh RR, Moore A, Werdecker A et al. The Global Burden of Cancer 2013. JAMA Oncol. 2015; 1(4): 505-527.

Citation:

Miguel López-Lázaro (2016) What is the Main Cause of Cancer? Can Stu The J Volume 1(1): 1-2 